\title{
Technology Fatigue of Faculty in Higher Education
}

\author{
Colleen Halupa* \\ Academic Affairs, East Texas Baptist University, One Tiger Drive, Marshall, TX 75670, U.S.A \\ E-mail: chalupa@etbu.edu \\ Doris U. Bolliger \\ Darden College of Education and Professional Studies, Old Dominion University \\ 5115 Hampton Boulevard, Norfolk, VA 23529, U.S.A. \\ E-mail: dorisbolliger@gmail.com
}

\begin{abstract}
The study investigated technology fatigue in instructors employed at three universities located in the United States. Instructors at three private institutions of higher learning located in two states were invited to complete an online survey that was developed by the researchers. Technology fatigue was operationalized as technology-use related stress (technostress) and frequent change in technology (change fatigue). A total of 171 valid responses were received from participants during a four-week period. Results show that they experienced moderate levels of technology fatigue. No statistically significant differences in responses were found based on the two types of learning environments (campus-based and online). Small differences were found based on the participants' gender. Respondents offered a variety of factors that contributed and mitigated their technology fatigue. Results are discussed within the context of the literature.
\end{abstract}

Keywords: Faculty, Technology utilization, Change fatigue, Technology stress

DOI: $10.7176 / \mathrm{JEP} / 11-18-02$

Publication date:June 30th 2020

\section{Introduction}

Technology is ubiquitous in many fields and has permeated higher education. Technology fatigue is becoming more prevalent in the developed countries of the world (Halupa, 2018). Faculty members who were trained in their fields before the advent of learning management systems and social media sometimes find it difficult to change their pedagogical methods to include the technology that Generation Z (those born between 1996 and 2015) desires because technology has always been present since their birth (Dimock, 2019). They never lived in a world without cell phones or the Internet. In addition, they may not be satisfied with the traditional facultycentered style of teaching. The Hechinger Report (2014) noted many faculty members do not believe technology actually improved learning outcomes and many instructors struggle with learning and keeping up with rapidly changing technology (Lederman \& McKenzie, 2017). The convergence of the old (faculty) and the new (students who want technology) can result in technology fatigue in university faculty.

\section{Literature Review}

Research about technology fatigue in society started to become prevalent after the second decade of the $21 \mathrm{st}$ century. Although humanity has had a love affair with technology since its inception, the "bloom is off the rose" of technology, and people are reporting a higher incidence of technology overload. In its most extreme form, it is technology addiction. Information overload has been reported in the research in certain fields prior to the regular use of technology in higher education. This research primarily began with the analysis of excessive television watching and its perceived negative effects during the 1950s. In 1980, O'Reilly studied the negative impact of technology overload on personnel in the workplace. In the mid-1990s, literature on technology-related information overload began to appear (Reuters Business Information, 1996; Swash, 1998).

\subsection{Technology Overload}

There are several different aspects of technology overload. This can include gadget fatigue defined by Technopedia (2018) as "a state that occurs when a user becomes confused, indecisive and overwhelmed when selecting technological or digital gadgets" (para 1). Grandhi, Jones, and Hiltz (2005) defined technology overload (also called technostress) as something that causes cognitive and physical burdens due to overuse of multiple, complicated gadgets. La Torre, Esposito, Schiarra, and Chiapette (2019) noted the definition of technostress has changed from the 1980s when it was defined as the inability to cope with new information technology in a healthy manner, to the negative impact of physical or mental attributes caused directly or indirectly by technology. Ayyagari (2012) defined technostress as someone's inability to deal with information overload and technology, and found it decreases productivity and job satisfaction. Some Americans are not viewing technology as positively as before (80\% positive in 2014 compared to $69 \%$ positive in 2018) (Jiang, 
2018). In addition, technology overload can affect physical health (Okonoda et al., 2017). Symptoms can include headaches, stiff shoulders, eyestrain, backaches, difficulty sleeping, and depression. Additional symptoms can include decreased productivity, dissatisfaction with work, fatigue, and anxiety (Marchiori, Mainardes, \& Rodrigues, 2019).

With higher education in flux, faculty members are expected to perform more than ever before, and their workload is greatly increased (Flaherty, 2018). This can result in technology overload. Barley, Meyerson, and Grodal (2011) investigated the impact of e-mail on workload and subsequent stress. They noted e-mail became a “... symbol of overload" (p. 905). Because e-mail does not stop outside of regular work hours, participants felt they were losing control, which resulted in undue stress.

\subsection{Faculty Perceptions of Technology in the Higher Education Classroom}

Faculty members are not completely convinced that the use of technology is always necessary or has improved/facilitated student learning. Almost two-thirds of instructors who participated in a study regarding faculty attitudes towards technology felt the benefits of educational technology was exaggerated, particularly considering the significant financial investment universities and colleges have made in technology. Slightly over half of the respondents felt there were any gains in student learning. Most respondents admitted they did not use most of the technologies available to them, and half of faculty members felt technology was not helpful and only made their jobs more difficult and time consuming (Leder \& McMillan, 2017; Jaschik \& Lederman, 2016). Similar results were found by other researchers (Bolliger \& Wasilik, 2009; De Gagne \& Walters, 2010; Green, Alejandro, \& Brown, 2009; Wingo, Ivankova, \& Moss, 2017). When faculty members perceive technology causes additional work, they will be less satisfied with its use. Mamun, Rahman, and Danaher (2015) found instructors spend approximately 43 hours a week using technology.

\subsection{Technology Stress}

While some researchers and experts call for the increased use of technology in higher learning to improve learning outcomes, faculty members who are not technologically adept become overwhelmed. Although research regarding technology stress in the general populace and business settings has been conducted, there are few studies that investigated stress technology can cause faculty members. When higher education faculty experience stress caused by technology use, they either avoid using technology or they try to keep up with constant changes. Okonoda et al. (2017) evaluated technostress in a sample of 144 faculty and found $53 \%$ reported high stress due to technology use. Of the 53\%, 40\% felt stress negatively impacted their job performance. No significant relationships between age and gender were found, but those who had been teaching a decade were three times as likely not to report they suffered from technostress. Overall, participants found it difficult to keep their technology skills current.

There are contributing factors to technostress other than the sheer number of technology tools and systems available to faculty. Faculty members felt overwhelmed due to insufficient university resources for training and support (Buchanan, Sainter, \& Sauntersinter, 2013; Lederman \& McMillan, 2017). Another source of stress is the perception that students have better technology skills than the faculty. Faculty members also fear that they cannot detect issues such as students committing academic honesty violations (McGee, 2013; Stuber-McEwen et al., 2009).

A significant element of technostress is the perception of being available on a constant basis. In the past, students were limited to contacting instructors during class or during designated office hours. Today, due to technology and the flexible delivery of academic courses and degree programs, students perceive an increased availability of faculty members. Many students expect instructors to answer their e-mails or phone calls instantly. However, John Horrigan, associate director of research at Pew Internet, mentioned in an interview that faculty members need time away from students and job responsibilities to decompress (Sutter, 2009).

Çoklar, Effiti, and Şahin (2017) developed a technostress scale for teachers. In 2016, Çoklar, Efilti, Şahin, and Akçay (2016) conducted a research study with teachers in Turkey using this instrument and found medium levels of general technostress. Other researchers (Harahap \& Effiyanti, 2015) investigated relationships between technostress, technology acceptance, work overload, and job insecurity in vocational schools in Indonesia. They found teachers' technostress could be alleviated with buy-in for technology use.

Khan, Rehman, and Rehman (2013) conducted a study at universities in Pakistan and found a negative significant relationship between three elements of technostress (overload, invasion, and uncertainty) and job satisfaction in academic librarians. Burke (2009) investigated technological stress in nurse educators at a U.S.based institution. Results showed participants experienced technological stress, and administrative support was a key factor in the reduction of stress. 
is defined as "a weariness from stress" or "a state of indifference or apathy brought on by an overexposure to something" (Merriam-Webster, 2019, para. 1). Change fatigue is a known phenomenon that occurs when employees are exposed to too many changes at once, and saturation is reached (Bernerth, Walker, \& Harris, 2011; Meinert, 2015). The result can be stress. McMillan and Perron (2013) argue that change fatigue and change resistance are not the same. Change fatigue occurs when there is a difference in how someone perceives things should be, and how things truly are during times of change. Those who experience change fatigue are not resistant - rather they are overwhelmed by change.

Although researchers have developed instruments to measure change fatigue in different disciplines (Bernerth et al., 2011; McMillan \& Perron, 2013; Nunally, 2016), an instrument has not been developed to measure change fatigue in higher education faculty caused by technology integration and utilization. Researchers postulate that technology fatigue is a combination of both technostress and change fatigue. Someone may suffer one without the other; however, either can result in technology fatigue.

\subsection{Purpose and Research Questions}

Instructors can easily experience technology fatigue when they feel like they are expected to be available constantly. Particularly when course and/or program are delivered in hybrid or online environments, it requires flexibility of those who teach. This predicament can result in feelings of technology or information overload and the desire to disconnect for periods of time due to stress. In order for universities to offer proper support to the faculty, administrators need to understand the factors of technology fatigue. The literature on technology fatigue of instructors in higher education, however, is still limited. It was the purpose of the study to investigate instructors' perceptions regarding their feelings of technology fatigue. The following research questions guided the study:

1. What are university instructors' perceptions of technology fatigue?

2. What factors contribute to instructors' experienced levels of technology fatigue?

3. What would help instructors lower their level of technology fatigue?

4. Are there differences in responses based on individual differences (e.g., gender and delivery method)?

\section{Methodology}

\subsection{Setting and Sample}

The population included all instructors who taught at three private universities in the United States. Two institutions are in the state of Texas. One is a technical university with traditional as well as engineering and aviation programs that offers both extensive face-to-face and online courses. In 2018, the total student enrollment was over 3,100 (including approximately 1,000 dual credit students), and more than 80 full-time faculty members are employed. The other Texas-based institution is a liberal arts university with six fully online programs. The university has approximately 1,600 students enrolled; it also has 100 dual credit students. The university employs 80 full-time faculty. The third institution is a small liberal arts university in Maine and offers both face-to-face and online instruction. This university has over 15 fully online programs at the undergraduate and graduate level with an enrollment of over 2,700 students. It employs over 70 full-time faculty and makes extensive use of adjunct instructors.

All selected universities have a small instructional design and technology department (with fewer than three staff members on average), and they transitioned to new learning management systems (LMS) within the last 3 to 5 five years. The technical university in Texas and the liberal arts university in Maine offered non-mandatory training for instructors. Additional training opportunities are offered at these two universities. The liberal arts university in Texas required all full-time faculty and campus-based adjuncts to attend $3 \frac{1}{2}$ hours of mandatory training over a period of six months. Online instructors were required to attend a 1-hour session on how to use the LMS and received extensive training material and support. In addition, periodic training is offered, and new instructors go through 1 to 2-hour one-on-one training. Additionally, one faculty member and one instructional technologist are dedicated to support instructors.

\subsection{Participants}

Over half of respondents $(51.5 \%)$ were female and $45.5 \%$ were male. Three percent of individuals did not wish to disclose their gender. Instructors held a variety of ranks: assistant $(26.2 \%)$, associate $(15.2 \%)$, full professor $(16.1 \%)$, instructor $(3.6 \%)$, and adjunct instructor $(38.7 \%)$. Their experience teaching in a university setting ranged from 0 to 48 years $(M=12.4 ; S D=9.7)$. Most instructors who responded taught a combination of online and traditional courses $(49.7 \%)$ at their universities, whereas $37.3 \%$ taught only traditional and $12.7 \%$ taught only online courses.

\subsection{Data Collection}

The data were collected during a 4-week period during spring semester. Prior to the administration of the 
instrument, approvals from all institutional review boards were obtained. The procedure followed an approach suggested by Dilman, Smyth, and Christian (2014). All faculty regardless of academic rank or course delivery method at the selected institutions were invited to participate via e-mail. The invitation included information about the research study and an embedded link to an online questionnaire. The instrument was housed on a secure server at a university associated with one of the researchers. Participation of individuals was voluntary and anonymous, and no incentives were provided for the completion of the survey. In order to increase the response rate, two reminders were sent via e-mail.

\subsection{Instrument}

Researchers conducted an extensive literature search on technostress and change fatigue in order to develop 26 items on a 5-point Likert type-scale ranging from 1-strongly disagree to 5-strongly agree. It also included a slider item that measured daily experienced technology fatigue; the slider could be positioned on a spectrum from 0-none to 10-high. A panel of four individuals participated in an expert review panel prior to the administration of the instrument to the sample. The experts served at two higher education institutions and held the rank of associate professor. They had at least six years of teaching experience and worked in the following disciplines: counseling education, teacher education, nursing, and psychology. Experts were instructed to review the categories and questions; comment on the clarity and appropriateness of items; and add, modify or delete items. Their feedback resulted in the revision of two items and one item was deleted. The final version of the instrument included 32 items: 25 Likert items, one slider item, and four demographic and two open-ended question. Open-ended questions asked participants to share factors that contribute to their perceived level of technology fatigue and what might lower their level of technology fatigue.

After the data were collected, internal reliability analyses were conducted on the instrument and its two subscales. Cronbach's alpha for the instrument was high $(\alpha=0.95)$. The internal reliability coefficients were also acceptable for both subscales: technostress $(\alpha=0.89)$ and change fatigue $(\alpha=0.94)$. A Pearson correlation coefficient was generated to measure the relationship between the two subscales. The two subscales are significantly related $(r=0.84)$ at the .01 level. Based on these results, we can conclude that the instrument is a reliable instrument.

\subsection{Data Analysis}

A total of 177 instructors completed the online survey. However, six cases had one-third or more data missing and were deleted from the data set. No outliers were detected $(z= \pm 3.29)$ in the data set. Frequencies were calculated before four items were recoded, and descriptives were generated. New variables were created for the two subscales. Independent $t$ tests were run to ascertain differences in responses based on gender. An analysis of variance test was conducted to determine differences in responses based on course delivery methods. Responses to two open-ended questions were analyzed based on open coding. Categories were generated and compared to form emerging themes (Flick, 2006; Richards, 2009).

\section{Results and Discussion}

\subsection{Instructor Perceptions of Technology Fatigue}

Overall, results show that participating instructors were only moderately fatigued with technology. They reported a range from 0 to $10(M=4.14, S D=2.52)$ of daily experienced technology fatigue. On the total scale, participants' mean scores on the scale ranged from 1.00 to $4.52(M=2.75 ; S D=0.74)$. The mean scores on the two subscales were similar: technostress $(M=2.83 ; S D=0.71)$ and change fatigue $(M=2.67 ; S D=0.83)$. These results were surprising given that fact that the literature points towards the pace of change regarding the utilization of technological innovations in higher education (Grajek \& Reinitz, 2019). Entering college students have an "information-age mindset" (Frand, 2000, p. 16). They have grown up with technology embedded in their lives. They are used to having instant access to information and constant connectedness to others. According to Dahlstrom and Bichsel (2014), "More students own mobile devices now than ever" (p. 4) and many students use them for learning. In general, students have positive attitudes toward technology use for learning. The integration of instructional technology is expected and appreciated by students (Gosper, Malfroy, \& McKenizie, 2013).

4.1.1 Technostress

The three items with the highest mean scores on this subscale pertained to respondents' desire to avoid using technology some days because they needed downtime $(M=3.57)$, technology making it difficult for them to take a break $(M=3.49)$, and them feeling like they were always working because of technology $(M=3.47)($ Table 1$)$. The three items with the lowest mean scores were items 22, 24, and 25 . Over $80 \%$ of participating instructors indicated they liked using technology $(M=2.08)$, and they agreed or strongly agreed that they thought they learned the use of new technologies very quickly $(M=2.36)$. The majority of respondents $(63.7 \%)$ strongly disagreed or disagreed that they felt overwhelmed with technology $(M=2.39)$. 
Table 1. Frequencies and descriptives for items on the technostress subscale $(N=171)$

\begin{tabular}{|l|c|c|c|c|c|}
\hline & \multicolumn{2}{|c|}{ Percentage } & \multicolumn{1}{|c|}{} \\
\hline Item & $S D / D$ & $N$ & $A / S A$ & $M$ & $S D$ \\
\hline $\begin{array}{l}\text { 6. It takes a significant amount of time to meet my students' expectations in } \\
\text { regards to use of educational technology in class. }\end{array}$ & 49.7 & 22.8 & 27.5 & 2.75 & 1.04 \\
\hline $\begin{array}{l}\text { 7. It takes a significant amount of my time to meet administration's } \\
\text { expectations in regards to use of educational technology in class. }\end{array}$ & 49.1 & 24.6 & 26.3 & 2.71 & 1.07 \\
\hline $\begin{array}{l}\text { 12. I do not have time to learn all of the functions of my learning } \\
\text { management system. }\end{array}$ & 35.0 & 19.3 & 45.6 & 3.11 & 1.19 \\
\hline $\begin{array}{l}\text { 15. I feel as if I am always "on" the job because of technology. } \\
\text { 16. Technology makes it difficult for me to take a break from work and/or } \\
\text { my students. }\end{array}$ & 26.9 & 14.6 & 58.5 & 3.47 & 1.22 \\
\hline $\begin{array}{l}\text { 17. There are days when I do not want to use technology because I need a } \\
\text { break from it. }\end{array}$ & 27.4 & 12.3 & 60.2 & 3.49 & 1.22 \\
\hline $\begin{array}{l}\text { 18. I have stopped using one or more tools in the last year (e.g., social } \\
\text { media, listservs, gadgets etc.) because I am tired of technology. }\end{array}$ & 22.2 & 14.0 & 63.8 & 3.57 & 1.16 \\
\hline $\begin{array}{l}\text { 20. Technology has improved my job efficiency and allows me more time } \\
\text { for other things. [R] }\end{array}$ & 51.5 & 17.5 & 31.0 & 2.80 & 1.16 \\
\hline 21. I feel "mentally tired" due to the use of technology in teaching. & 29.8 & 21.6 & 48.5 & 2.80 & 1.07 \\
\hline 22. I feel overwhelmed by technology. & 49.2 & 26.9 & 24.0 & 2.69 & 1.00 \\
\hline 23. I feel apathetic towards educational technology. & 63.7 & 19.3 & 17.0 & 2.39 & 1.07 \\
\hline 24. Overall, I like using technology. [R] & 52.7 & 30.4 & 17.0 & 2.57 & 1.01 \\
\hline 25. I learn new technologies very quickly. [R] & 4.7 & 15.2 & 80.2 & 2.08 & 0.73 \\
\hline
\end{tabular}

Note. Scale ranging from 1-strongly disagree to 5-strongly agree. $[\mathrm{R}]=$ reversed item. $S A=$ strongly agree, $A=$ agree, $N=$ neither disagree nor agree, $D=$ disagree, $S D=$ strongly disagree.

We expected that instructors experienced higher levels of technology-related than they reported. Perhaps instructors are accustomed to using a variety of technology tools and platforms because many institutions have entered the age of digital transformation. Today, the integration and utilization of technology in the classroom it is no longer optional. Instructors are required to use a combination of technology-based instructional tools and platforms, and systems for reporting purposes. Another possible explanation is that participants have found ways to self-regulate their behaviors by establishing personal boundaries.

4.1.2 Change Fatigue

Participants seemed to be more indifferent about items on the change fatigue subscale compared to items on the technostress subscale. For example, approximately $25 \%$ of instructors responded neutral to seven of the 12 statements, and none of the items had a mean score of 3.00 or above (Table 2). Items 3, 19, and 11 had the three highest means. Over 40\% strongly disagreed or disagreed that technology became obsolete as soon as they learned how to use it $(M=2.90)$ and that technology changed too rapidly for them to keep up with changes $(M=$ 2.81). However, more than $40 \%$ agreed or strongly agreed that learning new technologies in order to implement them in their classrooms energized them $(M=2.90)$.

Items $2,8,5$, and 14 had the lowest mean scores. Instructors disagreed strongly or disagreed that they were tired of learning new technologies $(M=2.49)$, learning new technologies made them tired and frustrated $(M=$ $2.53)$, and tired of expectation regarding the use of new technologies $(M=2.58)$. They were also in disagreement that it was difficult to meet the expectations of their administrators $(M=2.58)$. 
Table 2. Frequencies and descriptives for items on the change fatigue subscale $(N=171)$

\begin{tabular}{|c|c|c|c|c|c|}
\hline & \multicolumn{3}{|c|}{ Percentage } & & \\
\hline Item & $S D / D$ & $N$ & $A / S A$ & $M$ & $S D$ \\
\hline $\begin{array}{l}\text { 1. I wish the use of technology in education would slow down so I could } \\
\text { catch up. }\end{array}$ & 45.0 & 32.2 & 22.8 & 2.71 & 1.06 \\
\hline $\begin{array}{l}\text { 2. I am tired of learning new educational technologies to implement in my } \\
\text { teaching. }\end{array}$ & 59.6 & 22.2 & 18.2 & 2.49 & 1.07 \\
\hline $\begin{array}{l}\text { 3. It seems as soon as I learn a new educational technology, it becomes } \\
\text { obsolete. }\end{array}$ & 42.1 & 24.6 & 33.4 & 2.90 & 1.03 \\
\hline $\begin{array}{l}\text { 4. It is exhausting trying to keep up with technology to be able to meet } \\
\text { students' expectations. }\end{array}$ & 52.6 & 25.7 & 21.6 & 2.61 & 1.04 \\
\hline $\begin{array}{l}\text { 5. It is difficult keeping up with technology to meet administration's } \\
\text { expectations. }\end{array}$ & 53.9 & 24.6 & 21.6 & 2.58 & 1.05 \\
\hline 8. Learning new educational technologies makes me tired and/or frustrated. & 59.7 & 16.4 & 24.0 & 2.53 & 1.12 \\
\hline 9. Learning new educational technologies takes up too much of my time. & 48.6 & 26.9 & 24.6 & 2.67 & 1.07 \\
\hline 10. Keeping up with educational technology changes is exhausting. & 54.9 & 22.2 & 22.8 & 2.61 & 1.04 \\
\hline $\begin{array}{l}\text { 11. The advances in educational technology occur so fast it is difficult to } \\
\text { keep up with them. }\end{array}$ & 46.2 & 25.1 & 28.7 & 2.81 & 1.02 \\
\hline $\begin{array}{l}\text { 13. I am tired of being expected to learn new educational technologies (e.g., } \\
\text { video capture, clicker programs, etc.). }\end{array}$ & 51.5 & 24.6 & 23.9 & 2.66 & 1.09 \\
\hline 14. I am tired of being expected to use new educational technologies. & 54.4 & 24.0 & 21.7 & 2.58 & 1.08 \\
\hline $\begin{array}{l}\text { 19. It energizes me to spend time learning new technologie } \\
\text { in the classroom. [R] }\end{array}$ & 34.5 & 24.0 & 41.5 & 2.90 & 1.06 \\
\hline
\end{tabular}

Note. Scale ranging from 1-strongly disagree to 5-strongly agree. $[\mathrm{R}]=$ reversed item. $S A=$ strongly agree, $A=$ agree, $N=$ neither disagree nor agree, $D=$ disagree, $S D=$ strongly disagree.

Change fatigue may impact higher education faculty more during specific time periods than others. For example, instructors may feel more stressed when systems are phased out or introduced to campus. However, as the literature points out, buy-in of faculty (Harahap \& Effiyanti, 2015) and administrative support (Burke, 2009) can alleviate stress.

\subsection{Contributing Factors}

One open-ended question invited respondents to share issues that contribute to their level of technology fatigue. A total of 145 instructors shared their perceptions which yielded a total of 181 issues and 12 categories (Table 3 ). Most comments addressed the constant factor such as being in front of the computer or a computer screen constantly and the perception that they were never "off" work. They reported the "constant expectation of quick responses to emails and other forms of communication," constant connectedness "all day, every day," and "pressure for constant student interaction/connection." They felt they could not "disconnect because of constant access to technology or felt they constantly need to check e-mail because they could be contacted at any time.

Table 3. Factor contributing to technology fatigue $(n=145)$

\begin{tabular}{|l|c|}
\hline Factors & $n$ \\
\hline Constant demands & 44 \\
\hline Inefficiency/Ineffectiveness & 22 \\
\hline Specific systems & 18 \\
\hline Learning/training & 16 \\
\hline Administration & 13 \\
\hline Physical effects & 13 \\
\hline Students & 12 \\
\hline Support & 10 \\
\hline Reliability/quality & 10 \\
\hline Technology changes & 10 \\
\hline Number of systems/tools used & 8 \\
\hline Specific instances & 5 \\
\hline
\end{tabular}

Note. Participants mentioned multiple factors.

Inefficiencies and ineffectiveness issues included spending or wasting time with evaluating or comparing technologies, reworking instructional material, reinventing the wheel, relearning processes, finding workarounds, or simply integrating technology. Personal issues were noted such as not being proficient, poor planning, or ineffectiveness. Others felt that technology was implemented without a good rationale and improvements were "only marginal." Respondents mentioned course management systems (CMSs), e-mail, and social media as 
elements that contributed to technology fatigue.

Sixteen instructors mentioned that training was an issue - either the lack of training, limited time or opportunities to learn about newly introduced instructional technologies. They reported they did not have a "safe space" to learn and experiment before applying them. Others did not like learning "on their own time" or using online tutorials.

The administration was a factor in 13 participants' fatigue. Here instructors mentioned the requirement of unrealistic response times to students (e.g., 24 hours). Instructors felt pressured to use a variety of online systems in teaching and completing administrative tasks. Some felt that technology was used "to solve problems that don't exist" and frequent changes cause stress. Thirteen individuals reported negative physical effects due to long hours of sitting without getting up.

Participants were frustrated about their accessibility because students contact them at any time, and some students expected "instantaneous" results and feedback. A few instructors spent too much time explaining system features to students and dealt with students' frustrations when glitches occurred. Support issues included insufficient support, unclear instructions, and not being able to find answers on the website. Instructors experienced stress when systems did not work properly. A few felt that their universities had selected poor quality platforms, hardware, or software.

Ten participants reported it was difficult to keep up with changes such as the implementation of the newest tools, change of features and versions, or upgrades. Some felt it took a lot of time and work to keep up, and some tools were implemented and replaced too quickly. Eight respondents were fatigued due to the number of online platforms, programs, and tools they had to use for "everything" in their workday. Five instructors reported they had technology fatigue only at the beginning of the semester or at the time a new platform was implemented. Other specific instances included when e-mails became too frequent or they needed to find assistance with solving a technology-related problem.

The overall number of issues mentioned by respondents was surprising since study participants reported relatively low levels of technology fatigue. Perhaps instructors do not experience high levels of fatigue because technology use is so ubiquitous in our society and workplaces. Change may be something employees have come to expect, especially when it relates to the innovation and use of technology. The digital transformation is under way and the faculty will need to constantly change and adapt. Technology is changing "with astonishing speed and with consequences that are difficult to predict" (Grajek \& Reinitz, 2019, para. 7).

\subsection{Mitigating Factors}

The second open-ended question asked instructors what would help them in lowering their level of technology fatigue. The 132 suggestions shared by those who completed the question addressed seven different categories: administration, support, self-efficacy, efficiency of tools, time to learn, specific tools, and students (Table 4). Four areas were mentioned regarding the administration: rationales, off time, choice, and compensation.

Table 4: Elements to lower technology fatigue $(n=138)$

\begin{tabular}{|l|c|}
\hline Elements & $n$ \\
\hline Administration & 35 \\
\hline Support & 32 \\
\hline Self-efficacy & 24 \\
\hline Tool efficiency & 16 \\
\hline Time (to learn) & 9 \\
\hline Specific tools & 8 \\
\hline Students & 8 \\
\hline
\end{tabular}

Note. Participants mentioned multiple elements.

Fifteen instructors felt that a limited number of platforms should be selected. Once selected, the administration should not make changes for some time. They indicated administrators should have good reasons for the selection of technology and existing tools should be streamlined. Others advocated for more in-person conversations instead of digital communication. Thirteen individuals advocated for policies to limit the availability of instructors to regular business hours and excluding weekends and holidays. They felt administrators should have more reasonable expectations and eliminate the need for constant and immediate communication.

Three areas emerged in the support category: training, directions, and technology support. Faculty requested more training opportunities that were effective and timely. Participants suggested offering in-house training opportunities. They thought support should be ongoing instead of offering "one-shot" workshops. The number of participants should be restricted, and workshops should be hands on with time to practice. Six respondents mentioned that handbooks and directions should be easy to find and understand. More (or better) technology support (e.g., FAQ pages) was mentioned by five instructors.

Twenty-four participants were aware that they had a personal choice in the way they responded to 
workplace demands. They mentioned finding technology-free zones or time periods in order to disconnect. Others limited times spent with specific applications, took more breaks, and set schedules for specific tasks. Sixteen respondents indicated it would be helpful to select programs or platforms that were easy to obtain and implement (e.g., stable, simple systems), more user-friendly systems (e.g., fewer clicks, global settings) or programs that were all encompassing, therefore eliminating multiple e-mail accounts.

Individuals commented they wanted more time to learn, experiment, implement, and perfect newly introduced technologies. This included longer lead times and opportunities to learn during university breaks. Specific programs or platforms that needed improvement were e-mail programs, CMSs, and online homework systems. Others thought students should be held more accountable for their own learning; however, students should also be provided with more guidelines and expectations, tutorials, training, and support.

\subsection{Differences in Responses}

4.4.1 Gender

Independent sample $t$ tests were conducted to ascertain differences in responses based on gender. No differences were found on the total mean scale sores, level, and mean scores on the subscales. The test, however, was significant for two scale items: $7[t(149)=2.32, p=.02]$ and $20[t(146)=3.16, p=.002]$. The confidence intervals for the difference in means ranged from 0.56 to 0.72 and 0.19 to 0.83 . Cohen' $d$ was 0.37 and 0.50 , respectively, which indicates a small and medium effect size. For both items, men had a higher mean score $(M=$ $2.88 ; M=3.04)$ than females $(M=2.49 ; M=2.53)$. Men agreed more than women that it took more time to meet administrator's expectations in using educational technology in class and disagreed more that technology improved their job efficiency. Neither Burke (2009) nor Okonoda et al. (2017) found that gender influenced instructors' experience of technology-related stress.

4.4.2 Environment

A series of analyses of variances were conducted to investigate differences in responses based on instructors' teaching environments: online, face-to-face or a combination of online and face-to-face. The tests did not reveal significant results on the scale, subscales, or items. In other words, participating instructors did not report different levels of technology fatigue based on teaching environments. This was an unexpected result because the researchers hypothesized that results would vary between instructors who taught only face-to-face and only online (Lederman, 2018). This assumption was based on the fact that instructors of online courses must integrate instructional and communication technologies (e.g., course management system, e-mail, etc.) in order to deliver a course, whereas instructors who teach face-to-face may not necessarily be required to integrated them. However, it is quite possible that faculty members realize the affordances of instructional technologies, particularly when they teach in a variety of learning environments (Lederman, 2018).

\subsection{Limitations and Future Research}

The study had some limitations. First, the research instrument was developed by the researchers. In order to avoid contamination of the sample, we were unable to determine the reliability prior to the data collection. However, the instrument underwent the process of expert review to ensure face validity. Second, the data were self-reported due to the nature of the study. Third, not all disciplines were included in the sample. Two of the three universities were liberal arts universities and one focused more on technical programs such as aviation and engineering. Fourth, all universities from which the sample was drawn were private institutions; therefore, the results may have limited generalizability to other populations, particularly larger and/or public universities. Last, the study was geographically limited as it included universities in only two states.

This study did not investigate perceptions of instructors who teach in blended environments, although some of the participants may have taught blended courses. Future research may investigate technology fatigue in instructors who teach primarily blended courses. Researchers may investigate whether faculty members at public universities or different areas of the country view technology fatigue differently and report different levels than participants in this study. A study that includes multiple disciplines, institutions, and geographic areas could overcome some of the limitations.

\section{Conclusion}

It was the purpose of the study to evaluate technology fatigue in faculty at three different private universities. Participating instructors reported a low to moderate level of fatigue due to technology utilization and change based on the instrument that was developed by the researchers. These results are encouraging because the literature points out how stress can have negative effects on job performance and physical and mental well-being on employees. Instructors who participated may have proper institutional support. Another possibility is that instructors may have found a way to balance their professional lives and use of technology. Some participants reported they have found ways to mitigate negative effects such as taking breaks or creating technology-free zones or times. 
However, responses to open-ended questions point to several different factors that create technology fatigue or stress related to technology use at the workplace. It is interesting that so many different stressors were reported by participants who did not experience high levels of technology fatigue. This begs the questions as to whether instructors at higher education institutions do not realize their true stress levels or whether they are used to their environment and have accepted the status quo. For example, one participant wrote, "I think it is just a part of life now, sort of like back pain for people whose jobs involve heavy lifting." This conundrum warrants further exploration and investigation.

Participants offered many mitigating factors pertaining to technology fatigue. The two elements that were mentioned most often included the administration and support. There is a need for executive management to recognize technology fatigue in faculty members that is caused by too frequent change, alleviate stress by communicating rationales, and offer proper levels of technology support and professional development opportunities. They may also create and implement policies regarding their expectations of instructors and consider wellness factors. We hope that our results can assist instructors and administrators in making good decisions regarding the implementation and utilization of instructional technologies and, therefore, facilitate future change processes on their campuses in a more effective and satisfying way.

Acknowledgements

We would like to thank our four expert reviewers for their valuable time and feedback: Drs. Jenny Mobley, Joan Strutton, and P.J. Winters at East Texas Baptist University, and Dr. Lynda Konecny at A.T. Still University. We are also grateful to all instructors who participated in the study and shared their perspectives on technology fatigue in the context of teaching in higher education.

\section{References}

Ayyagari, R. (2012). Impact of information overload and task-technology fit on technostress. Proceedings of the Southern Association for Information Systems Conference, Atlanta, Georgia. Retrieved from https://aisel.aisnet.org/sais2012/4

Barley, S. R. Meyerson, D. E., \& Grodal, S. (2011). E-mail as a source and symbol of stress. Organization Science, 22(4), 887-906. doi:10.1287/orsc.1100.0573

Bernerth, J. B., Walker, H. J., \&. Harris, S. G. (2011, December 1). Change fatigue: Development and initial validation of a new measure. Work and Stress, 25, 321-337. doi:10.1080/02678373.2011.634280

Bolliger, D. U., \& Wasilik, O. (2009). Factors influencing faculty satisfaction with online teaching and learning in higher education. Distance Education, 30, 103-106. doi:10.1080/01587910902845949

Buchanan, T., Sainter, P., \& Saunders, G. (2013). Factors affecting faculty use of learning technologies: Implications for models of technology adoption. Journal of Computing in Higher Education, 25, 1-11. doi:10.1007/s12528-013-9066-6

Burke, M. S. (2009). The incidence of technological stress among baccalaureate nurse educators using technology during course preparation and delivery. Nurse Education Today, 29, 57-64. doi:10.1016/j.nedt.2008.06.008

Çoklar, A. N., Efilti, E., \& Şahin, Y. L. (2017). Defining teachers' technostress levels: A scale development. Journal of Education and Practice, 8(21), 28-41. Retrieved from https://iiste.org/Journals/index.php/JEP/article/view/37926

Coklar, A. N., Efilti, E., Şahin, Y. L., Akçay. A. (2016). Investigation of techno-stress levels of teachers who were included in the technology integration processes. Turkish Online Journal of Educational Technology, Special Issue for INTE 2016, 1331-1339. (ERIC Document Reproduction Service No, ED575012)

Dahlstrom, E., \& Bichsel, J. (2014, October). ECAR study of undergraduate students and information technology, 2014. Louisville, CO: EDUCAUSE Center for Analysis and Research. Retrieved from https://library.educause.edu/ /media/files/library/2014/10/ers1406.pdf

De Gagne, J. C., \& Walters, K. J. (2010). The lived experience of online educators: Hermeneutic phenomenology. Journal of Online Learning and Teaching, $6(2)$. Retrieved from http://jolt.merlot.org/vol6no2/degagne_0610.pdf

Dilman, D. A., Smyth, J. D., \& Christian, L. M. (2014). Internet, phone, mail, and mixed-mode surveys: The tailored design method (4th ed.). Hoboken, NJ: Wiley.

Dimock, M. (2019, January 17). Defining generations: Where Millenials end and Generation Z begins. Pew Research Center. Retrieved from https:/www.pewresearch.org/fact-tank/2019/01/17/where-millennialsend-and-generation-z-begins

Flaherty, C. (2018, January 26). College and university administrators discuss how to thoughtfully reduce faculty duties to help them advance their best work. Washington, DC: Inside Higher Ed. Retrieved from https://www.insidehighered.com/news/2018/01/26/college-and-university-administrators-discuss-howthoughtfully-reduce-faculty-duties 
Flick, U. (2006). An introduction to qualitative research (3rd ed.). Thousand Oaks, CA: Sage.

Frand, J. L. (2000). The Information-age mindset: Changes in students and implications for higher education. EDUCAUSE Review, 35(5), 14-20.

Gosper, M., Malfroy, J., \& McKenzie, J. (2013). Students' experiences and expectations of technologies: An Australian study designed to inform planning and development decisions. Australasian Journal of Educational Technology, 29(2), 268-282. doi:10.14742/ajet.127

Grajek, S., \& Reinitz, B. (2019, July 8). Getting ready for digital transformation: Change your culture, workforce, and technology. EDUCAUSE Review. Retrieved from https://er.educause.edu/articles/2019/7/getting-readyfor-digital-transformation-change-your-culture-workforce-and-technology

Grandhi, S. A., Jones, Q., \& Hiltz, S. R. (2005). Technology overload: Is there a technological panacea? AMCIS 2005 Proceedings, 493. Retrieved from http://aisel.aisnet.org/amcis2005/493

Green, T., Alejandro, J., \& Brown, A. H. (2009). The retention of experienced faculty in online distance education programs: Understanding factors that impact their involvement, The International Review of Research in Open and Distance Learning, 10(3), 1-15. doi:10.19173/irrodl.v10i3.683

Halupa, C. (2018). Technology fatigue in faculty. In L. Gómez Chova, A. López Martínez \& I. Candel Torres (Eds.), Proceedings of the International Conference of Education, Research and Innovation (pp. 86238632). Valencia, Spain: IATED Academy. doi:10.21125/iceri.2018.0588

Harahap, K., \& Effiyanti, T. (2015). Technostress among educators: A revisit of the social cognitive perspective. Asia Pacific Journal of Contemporary Education and Communications Technology, 1(1), 108-120. Retrieved from https://apiar.org.au/wp-content/uploads/2015/08/APCAR_BRR718_ICT.pdf

Hechinger Report. (2014, December 12). Professors grow weary of idea that technology can save higher ed. U.S. News and World Report. Retrieved from https://www.usnews.com/news/college-oftomorrow/articles/2014/12/12/professors-grow-weary-of-idea-that-technology-can-salvage-highereducation

Khan, A., Rehman, H., \& Rehman, S. (2013). An empirical analysis of correlation between technostress and job satisfaction: A case of KPK, Pakistan. Pakistan Journal of Library and Information Science, 14, 9-15.

Jaschik, S., \& Lederman, D. (2016). The 2016 Inside Higher Ed survey of faculty attitudes on technology: A study by Gallup and Inside Higher Ed. Retrieved from https:/www.insidehighered.com/booklet/2016survey-faculty-attitudes-technology

Jiang, J. (2018, May 2). Millennials stand out for their technology use, but older generations also embrace digital life. Washington, DC: Pew Research Center. Retrieved from http://www.pewresearch.org/facttank/2018/05/02/millennials-stand-out-for-their-technology-use-but-older-generations-also-embrace-digitallife/

La Torre, G., Esposito, A., Sciarra, I., \& Chiapetta, M. (2019). Definition, symptoms and risk of techno-stress: A systematic review. International Archives of Occupational and Environmental Health, 92, 13-35. doi:10.1007/s00420-018-1352-1

Lederman, D. (2018, October 31). Conflicted views of technology: A survey of faculty attitudes. Washington, DC: Inside Higher Ed. Retrieved from https://www.insidehighered.com/news/survey/conflicted-viewstechnology-survey-faculty-attitudes

Lederman, D., \& McKenzie, L. (2017, October 30). Faculty buy-in builds, bit by bit: Survey of faculty attitudes on technology. Washington, DC: Inside Higher Ed. Retrieved from https://www.insidehighered.com/news/survey/faculty-buy-builds-bit-bit-survey-faculty-attitudestechnology

Mamun, S. A. K., Rahman, M. M., \& Danaher, P. A. (2015). The determinant of faculty attitude to academic (over-)workload: An econometric analysis. In A. N. M. Wahid \& C. R. Amarao (Eds.), Proceedings of the Australasian Conference on Business and Social Sciences 2015, Sydney (pp. 1070-1082). Sydney, Australia. University of Central Queensland.

Marchiori, D. M., Mainardes, E. W., \& Rodrigues, R. G. (2019). Do individual characteristics influence the types of technostress reported by workers? International Journal of Human-Computer Interaction, 35, 218230. doi:10.1080/10447318.2018.1449713

McGee, P. (2013). Supporting academic honesty in online courses. Journal of Educators Online, 10. doi:10.9743/jeo.2013.1.6

McMillan, K., \& Perron, A. (2013, April 2). Nurses amidst change: The concept of change fatigue offers an alternative perspective on organizational change. Policy, Politics, and Nursing Practice, 14, 16-32. doi:10.1177/1527154413481811

Meinert, D. (2015, April). Executive briefing: How to combat change fatigue. HR Magazine, 60(3). Retrieved from https://www.shrm.org/hr-today/news/hr-magazine/pages/0415-execbrief.aspx

Merriam Webster Dictionary. (2018). Fatigue. Retrieved from https://www.merriam webster.com /dictionary/fatigue 
Nunnelly, L, (2016). Minimizing change fatigue amongst directors and managers through introducing an authentic leadership style at a small university in the southwest United States. Unpublished doctoral dissertation. University of Liverpool, UK. Retrieved from https://livrepository.liverpool.ac.uk/3001679/1/H00026218_June2016.pdf

Okonoda, K. M., Tagurum, Y. O., Imo, C. O., Nwachukwu, V. A., Okoli, E. S., \& James, B. O. (2017). Prevalence and correlates of technostress among academic staff at the University of Jos, Nigeria. Journal of Medical Science and Clinical Research, 5, 18616-18624. doi:10.18535/jmscr/v5i3.57

O'Reilly, III, A. (1980). Individuals and Information overload in organizations: Is more necessarily better? Academy of Management Journal, 23(4), 684-696. doi:10.5465/255556

Reuters Business Information. (1996). Dying for information? An investigation into the effects of information overload In the UK and worldwide. New York: Reuters Business Information.

Richards, L. (2009). Handling qualitative data: A practical guide (2nd ed.). Thousand Oaks, CA: Sage.

Stuber-McEwen, D., Wiseley, P., \& Hoggatt, S. (2009). Point, click, and cheat: Frequency and type of academic dishonesty in the virtual classroom. Online Journal of Distance Learning Administration, 12(3). Retrieved from http://www.westga.edu/ distance/ojdla/ fall123/stuber123.html

Sutter J. D. (2009, June 10). Do you suffer from Internet fatigue? CNN. Retrieved from http://www.cnn.com/2009/TECH/06/10/pew.internet.fatigue/

Swash, G. (1998). UK business information on the internet. New Library World, 99(6), $238-242$. doi:10.1108/03074809810236793

Techopedia. (2018). Gadget fatigue. Retrieved from https://www.techopedia.com/definition/23488/gadgetfatigue

Wedro, B. (2019). Fatigue symptoms, causes, and treatment. MedicineNet. Retrieved from https://www.medicine net.com/fatigue/article.htm\#fatigue_definition_and_facts

Wingo, N. P., Ivankova, N. V., \& Moss, J. S. (2017). Faculty perceptions about teaching online: Exploring the literature using the technology acceptance model as an organizing framework. Online Learning Journal, 21(1)15-35. doi:10.10.24059/olj.v21i1.761 